\title{
"The seagull cry" in internal carotid artery dissection
}

Figure Brain MRI and transcranial color-coded sonography

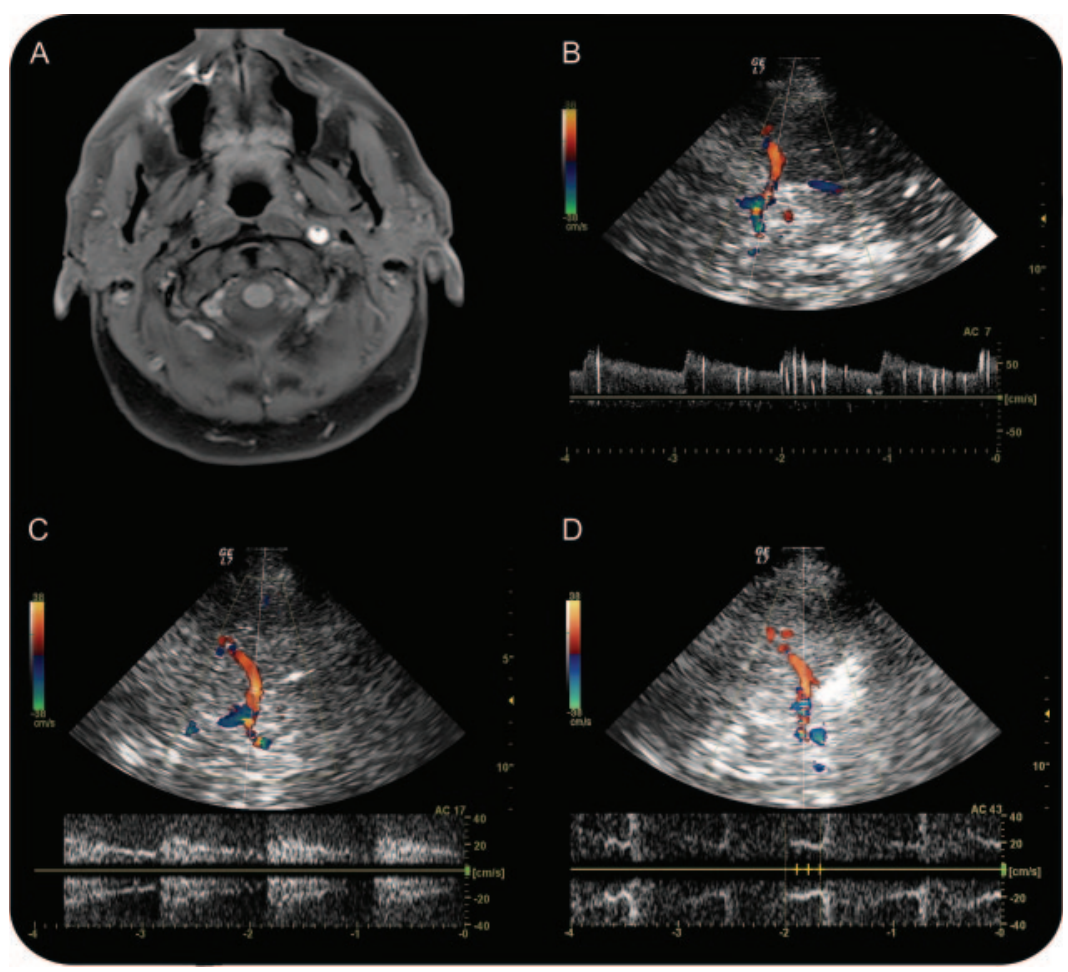

(A) Axial T1-weighted fat-suppressed imaging documented left internal carotid artery near occlusion with subacute intramural hematoma in its prepetrous tract. (B) Microembolic signals. (C, D) Doppler spectral analysis shows mirror-image parallel strings (visual correlate of a musical murmur) with different setting of pulse repetition frequency.

A 47-year-old man with left Horner syndrome due to left internal carotid artery dissection (figure, A) underwent transcranial color-coded sonography. Microembolic signals were detected in the left middle cerebral artery (figure, B). Doppler spectral analysis of the left intracranial carotid bifurcation displayed mirror-image parallel strings (figure, C and D), and high-frequency "seagull cry" was audible (audio file on the Neurology ${ }^{\circledR}$ Web site at www.neurology.org).

Musical murmurs (MMs), also called seagull cry, are murmurs with a single frequency that sounds like a musical tone. The phenomenon results from harmonic covibrations of the vessel wall caused by increased blood flow velocity. ${ }^{1}$ MMs have seldom been mentioned in cerebrovascular disease. The seagull cry in internal carotid artery dissection has not been observed to date.

Supplemental data at www.neurology.org

Supplemental Data

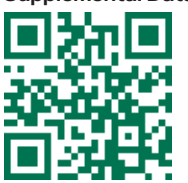

N. Morelli, MD, P. Immovilli, MD, L. Mazza, BS, E. Rota, MD, Piacenza, Italy; M. Spallazzi, MD, Parma, Italy; G. Rocca, $M D$, E. Michieletti, $M D, D$. Guidetti, $M D$, Piacenza, Italy

Author contributions: Study concepts: N. Morelli. Study design: N. Morelli. Data analysis/interpretation: M. Spallazzi, L. Mazza, P. Immovilli, N. Morelli. Manuscript preparation and definition of intellectual content: N. Morelli. Manuscript editing: N. Morelli. Manuscript revision/review: E. Rota, D. Guidetti, E. Michieletti.

Disclosure: The authors report no disclosures.

Address correspondence and reprint requests to Dr. Nicola Morelli, Guglielmo da Saliceto Hospital, Neurology Unit and Radiology Unit, Via Taverna 49, Piacenza 29100, Italy; n.morelli@inwind.it

1. Aaslid R, Normes H. Musical murmurs in human cerebral arteries after subarachnoid hemorrhage. J Neurosurg 1984;60:32-36. 


\title{
Neurology
}

\author{
"The seagull cry" in internal carotid artery dissection \\ N. Morelli, P. Immovilli, L. Mazza, et al. \\ Neurology 2011;77;1769 \\ DOI 10.1212/WNL.0b013e318236f140
}

\section{This information is current as of November 7, 2011}

\section{Updated Information \&}

Services

Supplementary Material

References

Subspecialty Collections

Permissions \& Licensing

Reprints including high resolution figures, can be found at: http://n.neurology.org/content/77/19/1769.full

Supplementary material can be found at: http://n.neurology.org/content/suppl/2011/11/06/77.19.1769.DC1

This article cites 1 articles, 0 of which you can access for free at: http://n.neurology.org/content/77/19/1769.full\#ref-list-1

This article, along with others on similar topics, appears in the following collection(s):

Carotid artery dissection

http://n.neurology.org/cgi/collection/carotid_artery_dissection Ultrasound

http://n.neurology.org/cgi/collection/ultrasound

Information about reproducing this article in parts (figures,tables) or in its entirety can be found online at:

http://www.neurology.org/about/about_the_journal\#permissions

Information about ordering reprints can be found online:

http://n.neurology.org/subscribers/advertise

Neurology ${ }^{\circledR}$ is the official journal of the American Academy of Neurology. Published continuously since 1951, it is now a weekly with 48 issues per year. Copyright Copyright (? 2011 by AAN Enterprises, Inc.. All rights reserved. Print ISSN: 0028-3878. Online ISSN: 1526-632X.

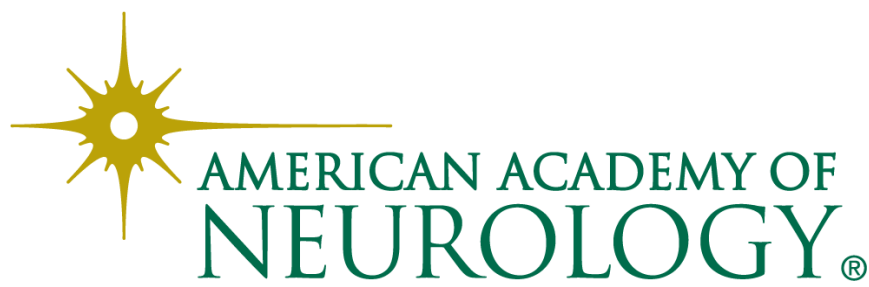

